\title{
The group process in school-age children for tuberculosis prevention behaviour
}

\author{
*Ikbal Fradianto ${ }^{1,2}$, Astuti Yuni Nursasi², Sukihananto ${ }^{2}$ \\ Sri Lanka Journal of Child Health, 2020; 49(3): 235-239
}

\begin{abstract}
Background: Tuberculosis (TB) attacks various ages, including school-age children. TB in children can make them lose more time in school and their growth and development are disrupted.
\end{abstract}

Objectives: This research assesses the effect of group process on behaviour, knowledge, attitudes, and skills prevention of TB in school-age children.

Method: This study used a quasi-experimental design, pre-post-test with a control group. It used multistage sampling, involving 63 children in the intervention group and 64 in the control group.

Results: In the intervention group, most children were 10 years old, male, with no family history of TB. Parental educational level was mainly junior high school and parental income level $\geq$ regional minimum wage. In the control group, most children were 11 years old, male, with no family history of TB. Parental educational level was mainly elementary school and parental income level $\geq$ regional minimum wage. There was a statistically significant effect of group process on behaviour, knowledge, attitudes and skills prevention of TB in school-age children $(\mathrm{p}<0.05)$.

Conclusions: Group process affected behaviour, knowledge, attitudes and prevention skills of TB in school-age children significantly.

http://dx.doi.org/10.4038/sljch.v49i3.9140

(Key words: School age children, prevention, health promotion, group process, tuberculosis)

\footnotetext{
${ }^{1}$ Nursing Study Program, Medical Faculty, Tanjungpura University, Indonesia, ${ }^{2}$ Faculty of Nursing, University of Indonesia

*Correspondence: ikbal.fradianto@ners.untan.ac.id

orcid.org/ 0000-0003-2408-5902
}

(Received on 20 September 2019: Accepted after revision on 18 October 2019)

The authors declare that there are no conflicts of interest

Personal funding was used for the project.

Open Access Article published under the Creative

Commons Attribution CC-BY (CC) (i) License

\section{Background}

Tuberculosis (TB) occurs mainly in the pulmonary parenchyma, but does occur in other organs ${ }^{1,2}$. School-age children are a vulnerable group affected by TB. In Indonesia 10\% children under the age of 15 had TB in 2015 which declined to $6.9 \%$ in $2016^{3,4}$. Health promotion efforts are a process of empowering someone to improve control and/or improve their health ${ }^{5,6}$. Health promotion in Indonesia in the school setting is carried out through the School Health Unit ${ }^{7}$. Trias UKS is health services, fostering a healthy school environment and health education ${ }^{8}$.

For giving health promotion in school-age children, the theory of health promotion model (HPM) can be used. HPM is a theory that explains the behaviour of prevention disease, but does not include fear or threat to the target, so that children are more motivated ${ }^{9}$. Group process is one of the health promotion strategies and will occur as peer interaction in the elementary school age environment. This is very useful for the continuity of the behaviour implementation because among friends in their groups can give a positive impact ${ }^{10}$.

Seeing the importance of TB in school-age children, especially in elementary school, for health promotion and prevention to risks of transmission, this can be done by providing health education by using the group process method.

\section{Objectives}

The purpose of this study was to determine the effect of group process on changes in TB prevention behaviour in school-aged children.

\section{Method}

This research is a quantitative one with a quasiexperimental design pre-post-test with control group. Multistage sampling technique was used. The intervention group comprised 63 respondents after the drop out of one respondent and the control group comprised 64 respondents. The study took place in the State Primary Schools in West Kalimantan, one school for the intervention group and one school for the control group, each group with different elementary schools. Intervention group children had 6 meeting sessions, 2 sessions per week for 3 weeks. The control group children were given traditional education or discussion once 
only. The evaluation was carried out after one week of giving the last intervention to the two groups. Ethical clearance was obtained from the Faculty of Nursing, Universitas Indonesia with the letter number No.43/UN2.F12.D/HKP.02.04/2018.

This study uses an instrument that has been modified by researchers Supriatun, Nursasi, \& Fitriyani in $2017^{11}$. Validity test results are obtained with the confidence of $95 \%(0.05), n=40$, so the $r$ table value is 0.312 . All questions both knowledge, attitudes and skills on the instrument got the value of $r$ count $>r$ table which has a valid meaning throughout the question and the Cronbach alpha value is 0.943 where the $r$ table value is 0.312 which means that it is reliable.

\section{Results}

An overview of the characteristics of respondents in this study is presented in Table 1 .

Table 1: Frequency distribution of respondent characteristics in intervention and control groups $(n=127)$

\begin{tabular}{|c|c|c|c|c|}
\hline \multirow[t]{2}{*}{ Characteristics of respondents } & \multicolumn{2}{|c|}{ Intervention Group $(n=63)$} & \multicolumn{2}{|c|}{ Control Group $(n=64)$} \\
\hline & n (\%) & Mean (SD) & n (\%) & Mean (SD) \\
\hline $\begin{array}{l}\text { Age (years) } \\
10 \\
11\end{array}$ & $\begin{array}{l}36(57.1) \\
27(42.9)\end{array}$ & $10.43(0.499)$ & $\begin{array}{l}30(46.9) \\
34(53.1)\end{array}$ & $10.53(0.503)$ \\
\hline $\begin{array}{l}\text { Gender } \\
\text { Male } \\
\text { Female }\end{array}$ & $\begin{array}{l}34(54.0) \\
29(46.0)\end{array}$ & & $\begin{array}{l}34(53.1) \\
30(46.9)\end{array}$ & \\
\hline $\begin{array}{l}\text { History of TB in the family } \\
\text { Present } \\
\text { Absent }\end{array}$ & $\begin{array}{l}02(03.2) \\
61(96.8) \\
\end{array}$ & & $\begin{array}{l}02(03.1) \\
62(96.9)\end{array}$ & \\
\hline $\begin{array}{l}\text { Parent educational level } \\
\text { No school } \\
\text { Primary School } \\
\text { Junior High School } \\
\text { Senior High School } \\
\text { University/College }\end{array}$ & $\begin{array}{l}09(14.3) \\
18(28.6) \\
26(41.3) \\
06(09.5) \\
04(06.3)\end{array}$ & & $\begin{array}{l}13(20.3) \\
24(37.5) \\
20(31.3) \\
06(09.4) \\
01(01.6)\end{array}$ & \\
\hline $\begin{array}{l}\text { Income level } \\
<\text { Regional minimum wage } \\
\geq \text { Regional minimum wage }\end{array}$ & $\begin{array}{l}14(22.2) \\
49(77.8) \\
\end{array}$ & & $\begin{array}{l}14(21.9) \\
50(78.1) \\
\end{array}$ & \\
\hline
\end{tabular}

Table 1 shows that most children in this study in the intervention group were 10 years old, male sex, did not have a family history of TB, junior high school education level and parents' income level $\geq$ regional minimum wage while in the control group most respondents were 11 years old, male gender, no family history of $\mathrm{TB}$, level of education of elementary school parents and parents' income level $\geq$ regional minimum wage. The respondents are normally distributed because the value of the skewness ratio is in the range of -2 to 2 and the homogeneity test results are homogeneous with the value of $p$ value $>0.05$.

Analysis of differences in the scores of TB prevention knowledge, attitudes and skills in school-age children before and after intervention in the intervention and the control groups is shown in Table 2.

Table 2: Analysis of differences in the scores of tuberculosis prevention knowledge, attitudes and skills in school-age children before and after intervention in the intervention and the control groups $(n=127)$

\begin{tabular}{|c|c|c|c|c|c|c|}
\hline \multirow[t]{3}{*}{ Variable } & \multicolumn{6}{|c|}{ Intervention Group } \\
\hline & \multicolumn{2}{|c|}{ Before } & \multicolumn{2}{|c|}{ After } & \multirow{2}{*}{ Different mean } & \multirow{2}{*}{ p-value } \\
\hline & Mean & SD & Mean & SD & & \\
\hline Knowledge & 5.38 & 2.773 & 8.62 & 1.007 & 3.238 & 0.001 \\
\hline Attitude & 21.43 & 8.780 & 33.68 & 3.232 & 12.254 & 0.001 \\
\hline Skills & 22.17 & 7.896 & 33.67 & 4.150 & 11.492 & 0.001 \\
\hline \multirow[t]{3}{*}{ Variable } & \multicolumn{6}{|c|}{ Control group } \\
\hline & \multicolumn{2}{|c|}{ Before } & \multicolumn{2}{|c|}{ After } & \multirow{2}{*}{ Different mean } & \multirow{2}{*}{ p-value } \\
\hline & Mean & SD & Mean & SD & & \\
\hline Knowledge & 05.08 & 3.020 & 05.23 & 2.877 & 0.156 & 0.115 \\
\hline Attitude & 21.30 & 9.249 & 20.52 & 8.233 & -0.781 & 0.033 \\
\hline Skills & 22.45 & 8.571 & 22.08 & 8.192 & -0.391 & 0.003 \\
\hline
\end{tabular}


The results of the analysis based on Table 2 in the intervention group was an increase in the mean knowledge score after the intervention of 3.328 , which is statistically significant $(p<0.05)$. There was an increase in the mean attitude score after the intervention of 12.254, which is statistically significant $(\mathrm{p}<0.05)$. There was also an increase in the skills score after the intervention of 11.492 , which is statistically significant $(\mathrm{p}<0.05)$.

The results of the analysis based on Table 2 in the control group was an increase in the mean knowledge after the intervention of 0.156 , which is statistically not significant $(\mathrm{p}>0.05)$. There was a decrease in the mean attitude score after the intervention of 0.781 which is statistically significant $(p<0.05)$. There was a decrease in the mean skills score after the intervention of 0.391 , which is statistically significant $(\mathrm{p}<0.05)$.

Analysis of differences in knowledge, attitudes and skills for prevention of TB in school-aged children after being given intervention between the intervention group and the control group is shown in Table 3.

Table 3: Analysis of differences in knowledge, attitudes and skills for prevention of tuberculosis in schoolaged children after being given intervention between the intervention group and the control group $(n=127)$

\begin{tabular}{|l|l|c|c|c|c|}
\hline Variable & \multicolumn{1}{|c|}{ Group } & Mean & Different mean & 95\% CI & p value \\
\hline \multirow{2}{*}{ Knowledge } & Intervention & 08.62 & 3.238 & -4.144 & \multirow{2}{*}{0.001} \\
\cline { 2 - 4 } & Control & 05.23 & 0.156 & -2.625 & \multirow{2}{*}{0.001} \\
\hline \multirow{2}{*}{ Skills } & Intervention & 33.68 & 12.254 & -15.370 & -10.964 \\
\cline { 2 - 4 } & Control & 20.52 & -0.781 & -13.890 & \multirow{2}{*}{0.001} \\
\cline { 2 - 4 } & Intervention & 33.67 & 11.492 & -9.318 & \\
\cline { 2 - 4 } & Control & 22.08 & -0.391 & & \\
\hline
\end{tabular}

The results of Table 3 analysis show that the influence of group process intervention on knowledge, attitude and skills variables were all statistically significant $(\mathrm{p}<0.05)$ which means that there is a significant influence of the group process on TB prevention in school-age children.

\section{Discussion}

Age affects the acceptance of health promotion given to school-age children, the acceptance being better with increasing age ${ }^{12}$. Prevention efforts carried out in this study provide better benefits, considering that gender is highly correlated with the incidence of $\mathrm{TB}^{13}$. School-age children who have families with TB in it have a very high risk of contracting $\mathrm{TB}^{14,15}$. Parents who have low education tend to find it difficult to convey information to their children ${ }^{16}$.

Significant changes in knowledge before and after group process can occur because, group process is one of the strategies carried out in health promotion. The group process will cause interaction between peers in the elementary school age environment, which is very useful for the continuity of the implementation of the behaviour given because friends in the group can give a positive impact ${ }^{17}$. Significant changes occur in the attitude of prevention of TB after being given a group process that can encourage children to determine what is right and what is wrong, so that children are able to take appropriate and correct attitudes specifically related to attitudes in preventing $\mathrm{TB}^{2}$. Changes in $\mathrm{TB}$ prevention skills that occur in the intervention group can occur because in the process groups, the children get not only information, but also children explain to every person at the group or practice TB prevention efforts that increases understanding related to TB prevention. Practices or demonstrations carried out between children during the group process make children not only understand but do it directly. Besides that, the group process also helps children to improve their skills, because there are interactions between children so that this helps children in doing something positive.

Based on the measurement of knowledge, attitude and skills overall, it was explained that group processes influence knowledge, attitudes and prevention skills of TB in school-age children. The group process carried out in this study can also increase social interaction at the age of school children. At this age it has also been formed where peers and the surrounding environment influence behaviour influences. Elementary schools are an optimal period for growth and development. They also can absorb the statement, approach the adolescence behaviour, increasing the reading and brain function. So children in elementary schools are very appropriate to be applied to group process $^{18}$. The stages that go through in the group process starting from forming to adjourning can be passed well and through this stage the child increasingly gives encouragement to change the behaviour of preventing TB for the better.

This research is also juxtaposed with the 4 pillars of TB prevention launched by the government. Three pillars can be compared in this study. The 
three pillars are: managerial by making a policy of implementing TB prevention group processes in all schools, administrative control by increasing socialization through group processes and selfprotection control by demonstrating to children using good and right masks. The next researcher needs to involve the family in his research because the family also has an important role in changing the behavior of school-age children. Further researchers can also use this group process for other health education materials that are also needed by school-age children, such as upper respiratory infections, diarrhoea and others.

\section{Conclusions}

The conclusion in this study is that the group process has been shown to significantly influence knowledge, attitudes and skills prevention of TB in school-age children

\section{Acknowledgments}

The researcher thanked several parties because this research took place because of the guidance from Dr. Astti Yuni Nursasi, S.Kp., M.N and Ns. Sukihananto, S.Kep., M.Kep.

\section{References}

1. Brunner .; Suddarth, (2013). Surgical Nursing Textbook Volume 2 (8th ed.). Jakarta: EGC.

2. Stanhope, M; Lancaster, J. (2016). Public health nursing (6th ed.). USA: Mosby Year Book

3. Ministry of Health of the Republic of Indonesia. (2016). Indonesian Health Profile.

4. WHO, W. H. O. (2017a). Global Tuberculosis Report 2017. Geneva.

5. Raingruber, B. (2011). Health education, health promotion and health: What do ehese definitions have to do with nursing? Contemporary Health Promotion in Nursing Practice, 1-24. Retrieved from https://books.google.com.au/books? $\mathrm{id}=\mathrm{Ge}$ Gq5tJlVHYC

6. WHO, W. H. O. (2017b). Health Promotion. Retrieved November 21, 2017, from

http://www.who.int/topics/health_promoti on/en/
7. Ministry of Health, Republic of Indonesia. 2015 Indonesia Health Profile. Available from:

http://www.depkes.go.id/resources/downlo ad/pusdatin/profil-kesehatan-

indonesia/indonesian $\% 20$ health $\% 20$ profile $\% 202015$.pdf

8. Gustina, E. (2017). School / Madrasah Health Business Background. Jakarta

9. Alligood, M. R. (2014). Nursing Theories and Their Work (8th ed.). Singapore: Elsevier Ltd.

10. Ogunsile SE, Ogundele BO. Effect of game-enhanced nutrition education on knowledge, attitude and practice of healthy eating among adolescents in Ibadan, Nigeria. International Journal of Health Promotion and Education 2016; 54 (5), 207-16.

https://doi.org/10.1080/14635240.2016.11 57509

11. Supriatun E, Nursasi AY, Fitriyani $P$. Enhancement of pulmonary tuberculosis with role play prevention behaviour among elementary school students. Comprehensive Child and Adolescent Nursing 2017; 40: 78-87. https://doi.org/10.1080/24694193.2017.13 86974

PMid: 29166188

12. Susanto T, Sulistyorini L, WuriWuryaningsih E, Bahtiar S. School health promotion: A cross-sectional study on Clean and Healthy Living Program Behavior (CHLB) among Islamic Boarding Schools in Indonesia. International Journal of Nursing Sciences 2016; 3(3): 291-8. https://doi.org/10.1016/j.ijnss.2016.08.007

13. Korua ES, Kapantow N, Kawatu PAT. (2014). Relationship between age, gender, and occupancy density with the incidence of pulmonary $\mathrm{TB}$ in outpatients at Noongan Regional General Hospital. Unsrat Journal, Faculty of K.

14. Sulistiyana CS, Susanti S. Relationship between knowledge and attitudes of families of lung tuberculosis patients with efforts to prevent lung tuberculosis in the work area of Kesunean Health Centre and Pengambiran Cirebon City. Tunas Medika Journal of Medicine \& Health 2017; 2(3): 
15. Yustikarini K, Sidhartani M. Factors for tuberculosis risk in children infected with Mycobacterium tuberculosis. Pediatric Sari 2016; 17(2):

https://doi.org/10.14238/sp17.2.2015.13640

16. Kobel S, Wirt T, Schreiber A, Kesztyüs D, Kettner S, Erkelenz N, et al. Intervention effects of a school-based health promotion program on obesity related behaviour outcomes, 2014.

https://doi.org/10.1155/2014/476230

PMid: 25328688 PMCid: PMC4190828
17. Gilbert GG, Sawyer RG, McNeill EB (2011). Health Education: Creating strategies for school and community health (Third Edition). United States: Jones and Bartlett Publishers. Retrieved from

http://books.google.co.za/books?id=cAcY 8L5wAVIC

18. Potter PA, Perry AG. (2013). Fundamental of Nursing. St. Louis, Missouri: Elsevier Inc. 